\title{
In memory of professor Czesław Niżankowski, Head of the Department of Anatomy, Wroclaw Medical University
}

\author{
Ryszard R. Kacała ${ }^{1, A-D, F}$, Krzysztof Wronecki, ${ }^{2, B, C, E}$, Arkadiusz Kacała ${ }^{3, B-D}$, Zygmunt Domagała ${ }^{1, B, E}$, Michał Porwolik ${ }^{1, B, E}$ \\ ${ }^{1}$ Department of Anatomy, Wroclaw Medical University, Poland \\ 2 Faculty of Physical Education and Physiotherapy, Opole University of Technology, Poland \\ ${ }^{3}$ Department of General Radiology, Interventional Radiology and Neuroradiology, Wroclaw Medical University, Poland \\ A - research concept and design; B - collection and/or assembly of data; C - data analysis and interpretation; \\ $D$ - writing the article; $E$ - critical revision of the article; $F$ - final approval of the article
}

Address for correspondence

Ryszard R. Kacała

E-mail:rkacala@cornetis.pl

Funding sources

None declared

Conflict of interest

None declared

Received on March 20, 2016

Reviewed on March 27, 2016

Accepted on June 17, 2016

\begin{abstract}
Professor Czesław Niżankowski was an academic teacher and researcher at several universities; head of the Department of Anatomy at Wroclaw Medical University (1966-1982); and head of the Department of Biological Sciences at the Wrocław School of Physical Education (since 1972 University School of Physical Education in Wrocław), as well as the chancellor there. He contributed greatly to the development of morphological sciences, supervising many doctoral and post-doctoral works. He dedicated considerable time to the preparation of anatomical specimens of lungs, hearts and organs of the gastrointestinal tract. At the Museum of Anatomy, there are over 100 specimens of lungs prepared using the forced air technique improved by Professor Niżankowski, along with specimens of the bronchial tree and vascular system prepared using a corrosive technique. Professor Niżankowski was an active member of scientific societies in Wrocław and in other cities in Poland. For his accomplishments, he received a number of ministerial and state awards, including the Knight's Cross of the Order of Polonia Restituta, and was granted an honorary doctorate by Wroclaw Medical University.
\end{abstract}

Key words: Czesław Niżankowski, history of anatomy, Polish medical universities, Department of Anatomy

DOI

10.17219/acem/63743

Copyright

Copyright by Author(s)

This is an article distributed under the terms of the

Creative Commons Attribution Non-Commercial License

(http://creativecommons.org/licenses/by-nc-nd/4.0/) 


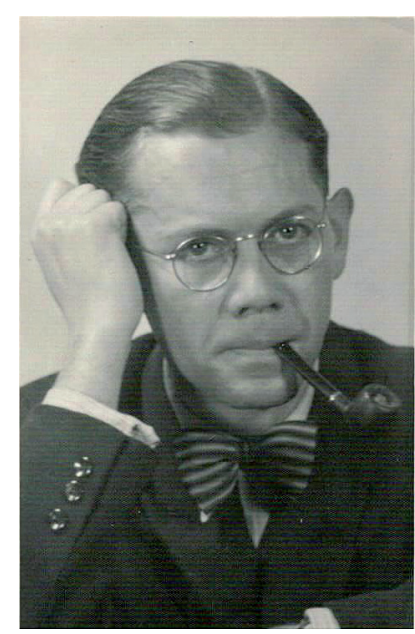

1. Professor Niżankowski with his favorite pipe

The life of Professor Czesław Niżankowski is linked with three Polish cities. He was born on July 14, 1914, in Kraków, and spent his childhood and most of his teenage years there until 1932. In Lviv, were he studied, he took his first job at the university and lived there until the autumn of 1944. After the war, he moved to Wrocław, where he lived and worked from 1945 onward. This reflects a pattern shared by many Poles in the $20^{\text {th }}$ century, whose lives were affected by World War II and who had to change their places of residence.

Czesław Niżankowski, son of Jan Niżankowski, a civil servant, and Zofia, née Klinger, a housewife, spent his childhood, along with his sister Jadwiga and his brother Adam, at 12 Topolowa Street in Kraków. Professor began his studies in Kraków in 1931 at the Department of Philosophy. ${ }^{1}$ After one year, he moved to Lviv, where, starting in 1932, he was a student of veterinary medicine at the Lviv Academy of Veterinary Medicine, completing his studies on March 18, 1937, without defending his degree. On November 25, 1939, due to the war, the Council of Professors made a resolution to delay the diploma examination until August 31, 1940. ${ }^{2}$ On October 28, 1940, Czesław Niżankowski passed the state examination in Lviv, at that time a part of the Soviet Union (the university was known as the Lviv Veterinary Institute). In 1939, during his studies, he began to work as a volunteer at the Department of Comparative Anatomy. After that, he worked as an acting assistant (October 2, 1935 - November 15,1937) and a junior assistant (November 15, 1937 - September 1, 1939). Throughout the war, he worked as a senior assistant (November 12, 1939 - September 12,1944). ${ }^{3}$

Czesław Niżankowski's interests went beyond veterinary medicine; he also studied medicine in Lviv at the Faculty of Medicine of Jan Kazimierz University from 1932 to 1937 . He continued his studies during the war, from 1941-1942 (student record book 146/42), but did not complete them due to the war. In autumn 1944 he moved back to Kraków after receiving a Kennkarte (a German identity document) on October 3, 1944. He stayed in his hometown until the end of the war. In March 1945 he was admitted

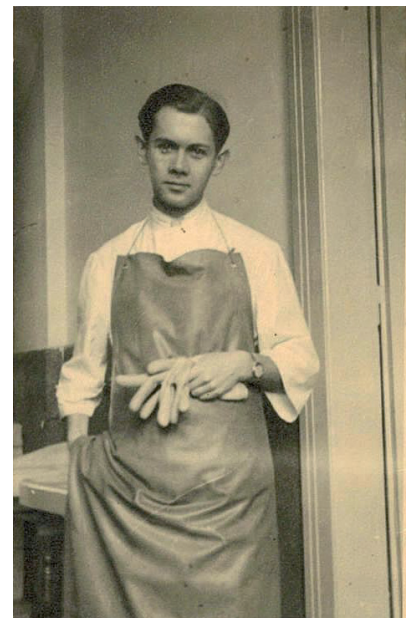

2. Young Czesław Niżankowski in a lab coat

to the $5^{\text {th }}$ year of medical studies at Jagiellonian University in Kraków, ${ }^{4}$ but received his Doctor of Medicine degree in Wrocław, where he passed his final examinations. ${ }^{5}$

Like many other scientists from Lviv, in the autumn of 1945 Niżankowski moved to Wrocław, which had been regained by Poland and was being repopulated by migrants, mostly from eastern regions of the country. Wrocław had been severely devastated during the war and working there required considerable sacrifice and dedication.

Niżankowski began his academic career as a senior research assistant on December 1, 1945, at the Department of Comparative Anatomy of the Faculty of Veterinary Medicine at the new combined University of Wrocław and Wrocław University of Science and Technology. ${ }^{6}$ In 1946, he received his doctorate in veterinary medicine. In 1947 Niżankowski was moved to the Faculty of Medicine and began work as a senior research assistant in the Department of Anatomy, headed by Professor Tadeusz Marciniak. ${ }^{7,8}$ From 1946 to 1950 Niżankowski held anatomy classes at the Institute of Physical Education at University of Wrocław and Wrocław University of Science and Technology. Then, once the Wrocław School of Physical Education (WSWF) was established, he became a lecturer in anatomy and biomechanics there, continuing this work until 1970.

The newly established WSWF needed experienced staff, and Dr. Czesław Niżankowski was appointed to the position of deputy professor, becoming the head of the Department of Biological Science at the WSWF from 1950 to 1970 . He was the dean of the WSWF from 1958 to 1965 ,when he succeeded Professor Tadeusz Marciniak as the chancellor of the school (in 1972 renamed University School of Physical Education in Wrocław), a position he held until 1990. ${ }^{9}$ It was during Niżankowski's years as chancellor, in December 1966, when the Wrocław School of Physical Education became the second in Poland qualified to grant PhD degrees (the first being in Warszawa). This was an important milestone, increasing the ranking and scientific prestige of University of Wrocław.

From 1947 to 1964, Niżankowski also lectured in anatomy for artists at the State College of Fine Arts in Wrocław 


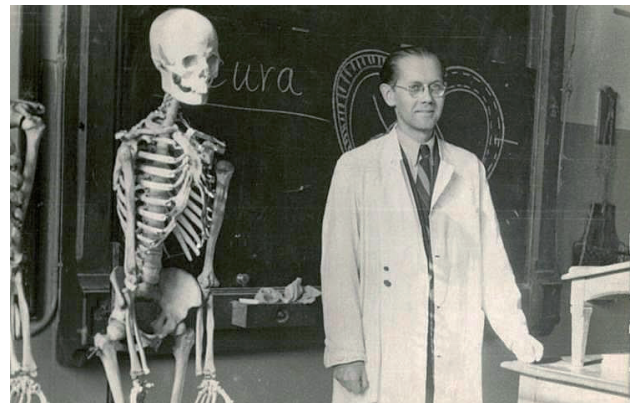

3. Professor Czesław Niżankowski at a lecture in anatomy

(1947-1964), and starting in 1966 he taught normal human anatomy for anthropology students at the Department of Natural Sciences at University of Wrocław. ${ }^{10}$ However, the principal place of employment for Professor Niżankowski was the Department of Descriptive Anatomy in the Faculty of Medicine, where he worked as a senior research assistant beginning on September 1, 1947. ${ }^{11}$ He taught classes and was one of the closest colleagues of Professor Tadeusz Marciniak. From September 1, 1953, Niżankowski was employed as a senior research assistant at Wroclaw Medical University. ${ }^{12}$ He was responsible for the teaching process in the Department of Anatomy. In 1961, Niżankowski defended his post-doctoral thesis entitled "The Typology of Coronary Heart Disease in Man", which was one of the major achievements in the field of morphology at Wroclaw Medical University during the 20-year-long history of the Polish People's Republic. ${ }^{13}$ In 1962, he was appointed assistant professor, and held this position until 1966.

After the death of Professor Marciniak, Niżankowski became the head of the Department of Anatomy (19661982). His work at the Department of Anatomy was mainly focused on teaching: giving lectures, teaching classes and mentoring young researchers. Interestingly, each of the junior and senior research assistants had to sit with Professor Niżankowski and take exams in anatomical knowledge, despite the fact that they themselves were teaching classes. He dedicated considerable time to the preparation of anatomical specimens of lungs, heart and organs of the gastrointestinal tract. At the Museum of Anatomy there are over 100 specimens of lungs prepared using the forced air technique, which was improved by Professor Niżankowski, and specimens of the bronchial tree and vascular system prepared using a corrosive technique. A separate group of specimens prepared using the corrosive technique includes injection-fixed human hearts that present the internal anatomy of the heart and organs of the gastrointestinal and urinary tracts. ${ }^{14}$

Starting in 1970, Czesław Niżankowski was also the director of the Institute of Biostructure at Wroclaw Medical University. His scientific interest was focused on the anatomy of the heart, lungs and gastrointestinal tract. During his academic career, he participated in international conventions of anatomists, and published 84 papers that he authored or co-authored. ${ }^{15}$ Many of these works were published in "Folia Morphologica", including:

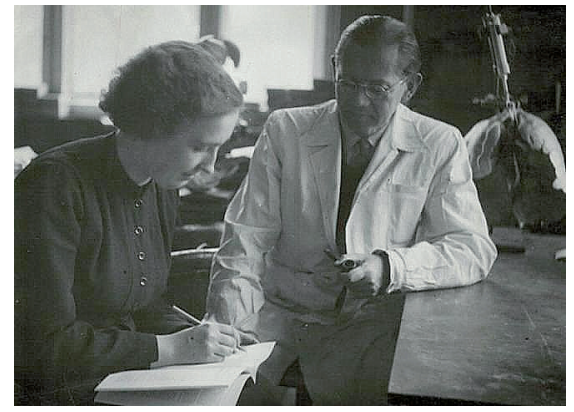

4. Professor Czesław Niżankowski discussing the research work of an assistant from the Department of Anatomy

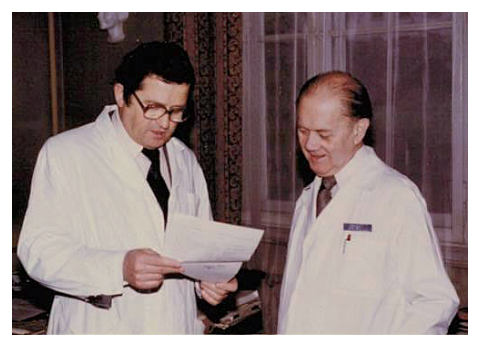

5. Professor Czesław Niżankowski with his future successor, Associate Professor Mieczysław Ziółkowski

"Abnormal Origin of Arteries from the Aortic Arch in Man"16

"Varieties of the Course of the Sciatic Nerve in Man"17

"Suggestion for a New Classification of the Shape of the Human Renal Pelvis with Consideration of the Number of Renal Papillae"18

"Studies on the Sciatic Nerve Course in Man in the Fetal Period"19

"Cor Biloculare in Man"20

"Contribution to Studies on the Apparent Ascent of the Spinal Cord in Human Fetuses"21

"Fossa Ovalis of the Interatrial Septum in Humans"22

Niżankowski received the title professor extraordinarius in 1969, and professor ordinarius in 1976. In 1981, he was one of the organizers of the finals of Scapula Aurea, a competition for medical students in Poland. Professor Niżankowski retired in 1982, but remained an active researcher. ${ }^{23}$ In recognition of his many years of research and teaching, Wroclaw Medical University granted Czesław Niżankowski an honorary doctorate in 1983. During his many years of service as head of the Department of Anatomy, Professor Niżankowski actively supported young scholars, and was the supervisor for 19 doctoral dissertations:

1. Jarosińska A. Zależność pomiaru filipińskiego od wybranych cech morfologicznych $i$ wieku inteligencji u dzieci wrocławskich [Correlations Between the Philippine Measurement and Selected Morphological Traits, Age and Intelligence in Children from Wrocław]. Wrocław, Poland; 1967 [in Polish].

2. Golema M. Zmiany katowe w stawach ćwiczacego podczas wykonywania ćwiczeń z przyborami i ćwiczenia dwójkowego [Angular Changes in Human Joints While Exercising with Equipment and in Pairs]. Wrocław, Poland; 1967 [in Polish]. 
3. Socha S. Badanie zależności pomiędzy wybranymi cechami somatycznymi i sprawnościowymi a wynikami sportowymi u miotaczy [An Analysis of the Correlation Between Selected Somatic and Fitness Traits and Sports Performance in Throwers]. Wrocław, Poland; 1967 [in Polish].

4. Socha O. Budowa i funkcja stopy u ptywaków i osób nieuprawiajacych ptywania [The Anatomy and Function of the Foot in Swimmers and Non-Swimmers]. Wrocław, Poland; 1969 [in Polish].

5. Soczyński L. Przebieg żyty śledzionowej u człowieka w populacji polskiej [The Course of the Human Splenic Vein in Polish Population]. Wrocław, Poland; 1967 [in Polish].

6. Sygula JE. Przebieg naczyń krwionośnych okrężnicy człowieka w populacji polskiej [The Course of Blood Vessels in the Human Colon in Polish Population]. Wrocław, Poland; 1967 [in Polish].

7. Rajchel Z. Analiza cech kończyny dolnej w zależności od typu budowy ciata [An Analysis of Lower Extremity Traits Depending on the Type of Body Shape]. Wrocław, Poland; 1970 [in Polish].

8. Skarżyńska T. Cechy antropometryczne ręki i stopy człowieka w okresie prenatalnym [Anthropometric Characteristics of the Human Hand and Foot During the Prenatal Period]. Wrocław, Poland; 1971 [in Polish].

9. Ćwioro E. Przebiegoraz zespolenia tętnic nabrzusznych u człowieka w populacji polskiej [The Course and Anastomosis of Human Epigastric Arteries in Polish Population]. Wrocław, Poland; 1971 [in Polish].

10. Hanusiewicz A. Zmiany inwolucyjne połaczeń stawowych kregostupa u człowieka [Involutive Changes in Human Vertebral Joints]. Wrocław, Poland; 1971 [in Polish].

11. Stankiewicz S. Morfologia tętnic pęcherzyka żótciowego w obrazie rentgenowskim [Morphology of Arteries in the Gallbladder in X-Ray Images]. Wrocław, Poland; 1972 [in Polish].

12. Kędzia A. Zlewisko żylne w obrębie dołu i bruzdy bocznej mózgu [Venous Drainage Within the Cranial Fossa and Lateral Sulcus]. Wrocław, Poland; 1972 [in Polish].

13. Magnowski L. Zmiany w położeniu jelit ze szczególnym uwzględnieniem kątnicy i okrężnicy w okresie prenatalnym u człowieka [Changes in the Position of the Intestines, with Particular Consideration of the Cecum and Colon, During the Prenatal Period in Humans]. Wrocław, Poland; 1973 [in Polish].

14. Sikora ZS. Tętniczo-oskrzelowy uktad segmentarny płata górnego płuca lewego i jego odmiany w populacji polskiej [The Arterobronchial Segmental System of the Left Lung Lobe and Its Variants in Polish Population]. Wrocław, Poland; 1973 [in Polish].

15. Stępińska B. Zmiany kształtu $i$ wymiarów głowy noworodków pod wptywem porodu $i$ dynamika procesu normalizacji [Changes in the Shape and Dimensions of the Head in Newborns Caused by Delivery, and the Dynamics of the Normalization Process]. Wrocław, Poland; 1973 [in Polish].
16. Marek J. Badanie zmienności cech opisowych i pomiarowych ślinianki podżuchwowej w rozwoju prenatalnym u człowieka [An Analysis of Diversity in Descriptive and Measurable Traits of the Submandibular Salivary Gland in Humans]. Wrocław, Poland; 1977 [in Polish].

17. Kazimierczak-Gierlak L. Badania nad rozwojem trzustki człowieka w okresie płodowym [Studies on the Development of the Human Pancreas During the Fetal Period]. Wrocław, Poland; 1977 [in Polish].

18. Suder E. Typologia tętnicy udowej u człowieka w okresie ptodowym [Typology of the Human Femoral Artery During the Fetal Period]. Wrocław, Poland; 1978 [in Polish].

19. Kindli R. Rozwój kości gnykowej człowieka w okresie płodowym [The Development of the Human Hyoid Bone During the Fetal Period]. Wrocław, Poland; 1979 [in Polish].

Professor Czesław Niżankowski also supervised the preparation of three post-doctoral dissertations:

1. Goździecki S. Zwiazki cech kefalometrycznych i kraniometrycznych u człowieka [Correlations between Cephalometric and Craniometric Traits in Humans]. Wrocław, Poland; 1970 [in Polish].

2. Bożiłow W. Badania nad budowa i rozwojem eksteroreceptorów i proprioreceptorów człowieka w okresie prenatalnym [Studies on the Structure and Development of Human Exteroceptors and Proprioceptors During the Fetal Period]. Wrocław, Poland; 1972 [in Polish].

3. Ziółkowski M. Macica i jajowody w rozwoju płodowym u człowieka [Fetal Development of the Human Uterus and Fallopian Tubes]. Wrocław, Poland; 1976 [in Polish].

Professor Niżankowski was a member of many scientific societies in Wrocław: the Polish Anatomical Society, the Polish Anthropological Society, the Polish Medical Association and the Polish Copernicus Society of Naturalists in Wrocław. For his work at universities in Wrocław he was granted a number of medals, including the Meritorious Activist of Physical Culture Decoration, the Medal of the National Education Commission, Scientific Award of the City of Wrocław, the Gold Cross of Merit and the Knight's Cross of the Order of Polonia Restituta.

Professor Czesław Niżankowski was an ambitious and active scientist who supported and created the foundations of the study of anatomical sciences in Wrocław. He shared his knowledge for many years, giving numerous lectures and teaching students at four of Wrocław's universities. He was appointed to serve in the administration of both Wroclaw Medical University and the Wrocław School of Physical Education. The crowning achievements of his work were his elections to the post of chancellor of the Wrocław School of Physical Education (since 1972 University School of Physical Education in Wrocław) and to the post of director of the Institute of Biostructure at Wroclaw Medical University. Professor Nizankowski's legacy includes a large group of students who continue the development of anatomy departments at the universities in Wrocław. 


\section{References}

1. Identity Card issued by Jagiellonian University in Kraków on October 28, 1931.

2. Degree certificate from the Academy of Veterinary Medicine in Lviv.

3. Personal files of Czesław Niżankowski.

4. Student record book - Universitatis Cracoviensis - Facultatis Medicinae.

5. Degree certificate of Doctor of Medicine issued in Wrocław on June 30, 1951.

6. Employment document for the position of senior research assistant at the Department of Comparative Anatomy, School of Veterinary Medicine

7. Employment document for the position of senior research assistant at the Department of Descriptive Anatomy, School of Medicine.

8. Kacała RR, Woźniak S, Porwolik M, et al. Remembrance of Profes sor Tadeusz Marciniak - Lviv Tradition in Wrocław. Adv Clin Exp Med. 2015;24(1);173-178.

9. Information materials with the list of teachers and curricula for the academic year 1966-67, WSWF in Wrocław.

10. Private archive; document with the description of places of employment and work periods at universities in Wrocław.

11. Letter from the chancellor of Wrocław University of Technology, July 4, 1947.

12. Letter from the chancellor of the Medical Academy in Wrocław August, 1953.
13. Achievements in Morphology Within the 20-Year-Long History of the Polish People's Republic. Folia Morphol (Warsz). 1964;15(23)(4);345.

14. Specimens in the collection of the Museum of Anatomy at the Department of Anatomy, description by Professor Tadeusz Marciniak from the book "Medical Academy in Wrocław 1950-1960", 65-66.

15. Niżankowski C. Report from the $20^{\text {th }}$ Congress of Czechoslovak Morphologists, Brno September 25-29, 1972. Folia Morphol (Warsz). 1973;33(2).

16. Niżankowski C, Rajchel Z, Ziółkowski M. Abnormal origin of arteries from the aortic arch in man. Folia Morphol (Warsz). 1975;34(2).

17. Niżankowski C, Słociak J, Szybejko J. Varieties of the course of the sciatic nerve in man. Folia Morphol (Warsz). 1972;31(4).

18. Niżankowski C. Suggestion for a new classification of the shape of the human renal pelvis with consideration of the number of renal papillae. Folia Morphol (Warsz). 1978;37(4).

19. Niżankowski C, Ziółkowski M. Studies on the sciatic nerve course in man in the fetal period". Folia Morphol (Warsz). 1979;38(4).

20. Niżankowski C, Rajchel Z, Ziółkowski M. Cor biloculare in man. Folia Morphol (Warsz). 1976;35(1).

21. Niżankowski C, Kurlej W. Contribution to studies on the apparent ascent of the spinal cord in human fetuses". Folia Morphol (Warsz). 1982;41(1).

22. Niżankowski C, Ziółkowski M, Marek J, Rabczyński J. Fossa ovalis of the interatrial septum in humans". Folia Morphol (Warsz). 1982;41(4).

23. Proof of employment at the Medical Academy in Wrocław. 